\title{
Molecular Analysis of the Pathway for the Synthesis of Thiol Tripeptides in the Model Legume Lotus japonicus
}

\author{
Manuel A. Matamoros, ${ }^{1,2}$ Maria R. Clemente, ${ }^{2}$ Shusei Sato, ${ }^{3}$ Erika Asamizu, ${ }^{3}$ Satoshi Tabata, ${ }^{3}$ Javier \\ Ramos, ${ }^{2}$ Jose F. Moran, ${ }^{2}$ Jiri Stiller, ${ }^{1}$ Peter M. Gresshoff, ${ }^{1}$ and Manuel Becana ${ }^{2}$ \\ ${ }^{1}$ Department of Botany, University of Queensland, Brisbane, Australia; ${ }^{2}$ Departamento de Nutrición Vegetal, Estación \\ Experimental de Aula Dei, Consejo Superior de Investigaciones Científicas, Apdo 202, 50080 Zaragoza, Spain; ${ }^{3}$ Kazusa \\ DNA Research Institute, 1532-3 Yana, Kisarazu, Chiba, 292-0812, Japan.
}

Submitted 10 March 2003. Accepted 4 July 2003.

\begin{abstract}
The thiol tripeptides, glutathione (GSH) and homoglutathione (hGSH), perform multiple roles in legumes, including protection against toxicity of free radicals and heavy metals. The three genes involved in the synthesis of GSH and hGSH in the model legume, Lotus japonicus, have been fully characterized and appear to be present as single copies in the

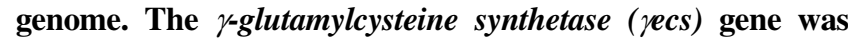
mapped on the long arm of chromosome 4 (70.0 centimorgans $[\mathrm{cM}]$ ) and consists of 15 exons, whereas the glutathione synthetase (gshs) and homoglutathione synthetase (hgshs) genes were mapped on the long arm of chromosome 1 (81.3 cM) and found to be arranged in tandem with a separation of approximately $8 \mathrm{~kb}$. Both genes consist of 12 exons of exactly the same size (except exon 1, which is similar). Two types of transcripts were detected for the gshs gene, which putatively encode proteins localized in the plastids and cytosol. Promoter regions contain cis-acting regulatory elements that may be involved in the plant's response to light, hormones, and stress. Determination of transcript levels, enzyme activities, and thiol contents in nodules, roots, and leaves revealed that recs and hgshs are expressed in all three plant organs, whereas gshs is significantly functional only in nodules. This strongly suggests an important role of GSH in the rhizobia-legume symbiosis.
\end{abstract}

Glutathione (GSH; $\gamma$ Glu-Cys-Gly) is an abundant metabolite in plants and other organisms, where it performs a multiplicity of functions. These include storage and transport of sulfur, scavenging of $\mathrm{H}_{2} \mathrm{O}_{2}$, control of cell cycle and redox status, and detoxification of xenobiotics and heavy metals (May et al. 1998; Zenk 1996). In some legume tissues, homoglutathione (hGSH; $\gamma$ Glu-Cys- $\beta$ Ala) can partially or completely replace GSH (Klapheck 1988; Matamoros et al. 1999). There is evidence that hGSH can share some functions with GSH, such as the transport of reduced sulfur from leaves to developing fruits (Macnicol and Bergmann 1984) and the antioxidative defense of nodules (Moran et al. 2000). However, the low hGSH concentration found in the chloroplasts of some legumes may be insufficient for $\mathrm{H}_{2} \mathrm{O}_{2}$ detoxification in the leaves (Zopes et al. 1993). The synthesis of GSH and hGSH involves two ATP-

Corresponding author: M. Becana; Telephone: +34-976-716055; Fax: +34-976-716145; E-mail: becana@eead.csic.es.

Nucleotide sequences were deposited in DDBJ/EMBL/GenBank databases under accession numbers AY204516 ( $\gamma$ ECS cDNA), AF279703 (GSHS cDNA), AY219337 (hGSHS cDNA), AY186541 (recs), AY233859 (gshs), and AY172654 (hgshs). dependent steps. The first reaction is common to both tripeptides and is catalyzed by $\gamma$-glutamylcysteine synthetase $(\gamma$ ECS $)$, whereas the second reaction is catalyzed by specific enzymes, glutathione synthetase (GSHS) or homoglutathione synthetase (hGSHS).

We have initiated a long-range molecular analysis of the antioxidants in the rhizobia-legume symbiosis using Lotus japonicus as a model legume. This species is particularly amenable for molecular and genetic studies because of its small genome $(2 n=12,450 \mathrm{Mb} / n)$, short generation time, abundant seed production, availability of symbiotic mutants, and ease of transformation (Handberg and Stougaard 1992). Surprisingly, there is no information about the antioxidant composition of $L$. japonicus or its bacterial symbiont, Mesorhizobium loti, despite the fact that the chloroplast (Kato et al. 2000) and bacterial (Kaneko et al. 2000) genomes already have been sequenced and that the nuclear genome is being sequenced at a fast pace (Nakamura et al. 2002; Sato et al. 2001).

In this work, the three genes involved in the synthesis of thiol tripeptides in L. japonicus have been fully characterized. The promoter regions of recs, gshs, and hgshs contain regulatory elements related to the plant's response to light, hormones, and stress conditions. However, some elements are found in only one or two of the promoters, suggesting differential gene regulation. We show here that yecs and hgshs are expressed in nodules, roots, and leaves, whereas $g s h s$ is fully functional only in nodules. This may reflect an important, and rather specific, role of GSH in the rhizobia-legume symbiosis.

\section{RESULTS}

Distribution of thiol compounds and

thiol synthetase activities.

The first step of this study was to determine the relative abundance of thiol tripeptides (GSH and hGSH) and associated biosynthetic enzyme activities (GSHS and hGSHS) in L. japonicus. Thiols were extracted in acid medium to precipitate proteins and minimize oxidation. Although the isolation of the nodule plant fraction was done in less than $5 \mathrm{~min}$, we cannot discard the possibility that a small proportion of the GSH found in nodules originated in the bacteroids. Enzyme activities were extracted with an optimized buffered medium containing glycerol to preserve enzyme activity and bacteroid integrity. In these conditions, the contamination of the nodule plant fraction with bacteroids, which have their own GSHS, is estimated to be negligible using marker enzymes (Moran et al. 2000).

In plants at the vegetative growth stage, hGSH accounts for $96 \%$ of the total tripeptides in roots and leaves but only 
$35 \%$ in nodules (Table 1). Also, hGSHS activity accounted for $>94 \%$ of the total thiol tripeptide synthetase activity in roots and leaves, whereas GSHS and hGSHS activities were roughly similar in nodules. The correlation between thiol contents and enzyme activities is consistent with the conclusion that GSH and hGSH are synthesized in legume tissues by specific thiol tripeptide synthetases (Frendo et al. 1999; Matamoros et al. 1999; Moran et al. 2000). Our results also indicate that the major thiol synthesized in L. japonicus plants is hGSH and that significant amounts of GSH are produced only in the nodules.

\section{Characterization of cDNAs and deduced proteins.}

The organ-dependent distribution of enzyme activities in $L$. japonicus prompted us to isolate clones encoding GSHS and hGSHS from nodule and leaf cDNA libraries, respectively. Only one expressed sequence tag (EST) (accession no. AV429187) was found in the databases for the hgshs gene and none for the gshs gene, which suggests a very low abundance of transcripts. Several GSHS and hGSHS clones were completely sequenced and at least four clones of each type were analyzed by $5^{\prime}$-rapid amplification of cDNA ends (RACE) to verify start codons. Interestingly, two in-frame ATG codons were present in the $5^{\prime}$ region of the hGSHS clones, but only the second ATG in the GSHS clones. Further experiments with primers designed to the genomic sequence upstream of the first ATG resulted in the isolation, from cDNA libraries or cDNA prepared from nodule RNA, of GSHS clones that contained the two ATG codons homologous to the hGSHS clones. Therefore, two populations of gshs transcripts appear to be present in nodules. The longest GSHS cDNA has an open reading frame (ORF) of 1,653 bp and encodes a protein of 550 amino acids and $61.3 \mathrm{kDa}$, and the hGSHS cDNA has an ORF of 1,638 bp and encodes a protein of 545 amino acids and $61.0 \mathrm{kDa}$ (Table 2). The amino acid sequences show $71 \%$ identity to each other and $>75 \%$ identity with the homologous enzymes of other legumes. The GSHS and hGSHS sequences contain a Gly-rich domain (KPQREGGGNNXYG) that is highly conserved among the GSHS proteins from yeasts, plants, and animals (Ullmann et al. 1996). This domain was identified as a flexible loop and presumably takes part of the catalytic active site

Table 1. Distribution of thiol tripeptides and thiol synthetase activities in plants of Lotus japonicus

\begin{tabular}{llll}
\hline Thiol or enzyme $^{\mathbf{a}}$ & Nodules & \multicolumn{1}{c}{ Roots } & \multicolumn{1}{c}{ Leaves } \\
\hline GSH & $188 \pm 11$ & $7 \pm 3$ & $22 \pm 3$ \\
hGSH & $102 \pm 10$ & $194 \pm 19$ & $540 \pm 26$ \\
GSHS & $10.3 \pm 0.9$ & $0.6 \pm 0.0$ & 0 \\
hGSHS & $12.4 \pm 0.6$ & $9.0 \pm 1.6$ & $11.1 \pm 1.0$ \\
\hline
\end{tabular}

${ }^{\mathrm{a}}$ Thiol contents (nmol g ${ }^{-1}$ fresh weight) are means $\pm \mathrm{SE}(n=12$ to 16 samples). Enzyme activities (nmol $\mathrm{min}^{-1} \mathrm{~g}^{-1}$ fresh weight) are means $\pm \mathrm{SE}(n=8$ to 12 samples). GSH = glutathione, hGSH = homoglutathione, GSHS = glutathione synthetase, and hGSHS = homoglutathione synthetase.
(Wang and Oliver 1997). Prediction programs of subcellular localization indicate that GSHS and hGSHS contain typical chloroplast signal peptides; however, the deduced GSHS protein starting with the second Met residue lacks any recognizable signal peptide for organelle targeting and, hence, is predicted to be localized in the cytosol (Table 2). These subcellular localizations are consistent with the presence of plastid and cytosol GSHS isoforms in pea and spinach (Hell and Bergmann 1990; Rennenberg 1997 ) and with the isolation of cDNA clones encoding a putative cytosolic GSHS in Arabidopsis (Ullmann et al. 1996).

To complete this part of the work, we isolated a cDNA clone encoding $\gamma \mathrm{ECS}$, the first enzyme of the pathway. The $\gamma$ ECS clone was isolated on the basis of a single EST (MR068f07), obtained from a root cDNA library, within the framework of the L. japonicus genome sequencing project at the Kazusa DNA Research Institute (Japan). No EST sequences encoding $\gamma$ ECS could be detected in leaf or nodule cDNA libraries. This indicates that the recs transcript, as occurred with the gshs and hgshs transcripts, is scarcely represented in the cDNA libraries generated from nodules, roots, or leaves of young plants. The complete $\gamma$ ECS cDNA has an ORF of $1,488 \mathrm{bp}$ that encodes a protein of 495 amino acids and $55.9 \mathrm{kDa}$ (Table 2). The deduced protein sequence is 83 to $88 \%$ identical to the enzymes of other higher plants and is predicted to contain a signal peptide, probably for plastid targeting. The same localization was proposed for the $\gamma \mathrm{ECS}$ of pea and spinach, although activity also was detected in the cytosol (Hell and Bergmann 1990).

The amino acid sequences of $\gamma$ ECS, GSHS, and hGSHS were used to generate phylogenetic trees (Fig. 1). The $\gamma$ ECS proteins clustered in three groups (percent identity relative to the L. japonicus $\gamma \mathrm{ECS}$ is indicated in parentheses): proteobacteria (56 to 60\%), Arabidopsis and Indian mustard (83\%), and legumes and other important crops (80 to 90\%). The $\gamma$ ECS sequences from Escherichia coli and Salmonella typhimurium (18\%), yeast (27\%), and animals (26\%) had to be excluded from the analysis due to their very low homologies. The sequences of GSHS and hGSHS were also grouped in three clusters (percent identities with the L. japonicus GSHS and hGSHS are indicated in parentheses): legumes (70 to $90 \%$ ), other higher plants (63 to 70\%), and yeast and animals (37 to $44 \%$ ).

\section{Characterization of genes.}

Partial cDNA sequences encoding $\gamma \mathrm{ECS}$, GSHS, and hGSHS were used to screen transformation-competent artificial chromosome (TAC) libraries. The respective genes were identified and their structure determined by comparison of cDNA and genomic sequences (Fig. 2). The recs gene was mapped on the long arm of chromosome 4 (70.0 centimorgans [cM]) and consists of 15 exons (69 to $245 \mathrm{bp}$, excluding the untranslated regions [UTRs]), interrupted by 14 introns (71 to $846 \mathrm{bp}$ ). The gshs and hgshs genes were mapped on the long arm of chromosome $1(81.3 \mathrm{cM})$ and found to be arranged in

Table 2. Predicted properties of thiol synthetases from Lotus japonicus

\begin{tabular}{|c|c|c|c|c|c|}
\hline Enzyme $^{a}$ & Molecular mass ${ }^{\mathbf{b}}$ & $\mathbf{p I}^{\mathbf{c}}$ & Length $^{d}$ & Subcellular localization $^{\mathrm{e}}$ & Observations \\
\hline$\gamma \mathrm{ECS}$ & 55.9 & 6.22 & 495 & Only in plastids? & Ambiguous signal peptide \\
\hline GSHS $^{\mathrm{f}}$ & $55.0 / 61.3$ & $6.17 / 8.17$ & $493 / 550$ & Plastids and cytosol & Putative chloroplast signal peptide of 58 amino acids \\
\hline hGSHS & 61.0 & 6.04 & 545 & Plastids and cytosol & Putative chloroplast signal peptide of 54 amino acids \\
\hline
\end{tabular}

\footnotetext{
${ }^{\mathrm{a}} \gamma \mathrm{ECS}=\gamma$-glutamylcysteine synthetase, GSHS $=$ glutathione synthetase, and hGSHS $=$ homoglutathione synthetase.

b Theoretical molecular mass in kilodaltons.

${ }^{\mathrm{c}}$ Isoelectric point of the preprotein calculated by ExPASy (Expert Protein Analysis System).

${ }^{\mathrm{d}}$ Number of amino acid residues of the preprotein.

${ }^{\text {e }}$ Predicted subcellular localization based on ChloroP, Target P, PSORT, and MitoProt programs.

${ }^{\mathrm{f}}$ Values for the GSHS products deduced from the two types of transcripts.
} 
tandem with a separation of $8 \mathrm{~kb}$. Both genes consist of $12 \mathrm{ex}-$ ons of exactly the same size (70 to $193 \mathrm{bp}$, excluding the UTRs), except for exon 1 , which is very similar. There are, however, some significant differences in intron size for the two genes, in particular in introns 1 and 9. All exon-intron junctions of the three genes conform to the GT/AG rule for splicing described for eukaryotic genes (Shapiro and Senapathy 1987), except for introns 6 of $g s h s$ and hgshs, which show an AT/AC splicing. Comparative analyses of genomic Southern blots and restriction maps suggest that recs, gshs, and hgshs are present as single-copy genes in the L. japonicus genome (Fig. 3).

The promoter regions of jecs, gshs, and hgshs had not been examined so far for any legume. Because the exact transcription start site is unknown, only the first $800 \mathrm{bp}$ upstream of the start codon were considered in a computer-assisted search for cis-acting regulatory elements. The promoter regions of one or
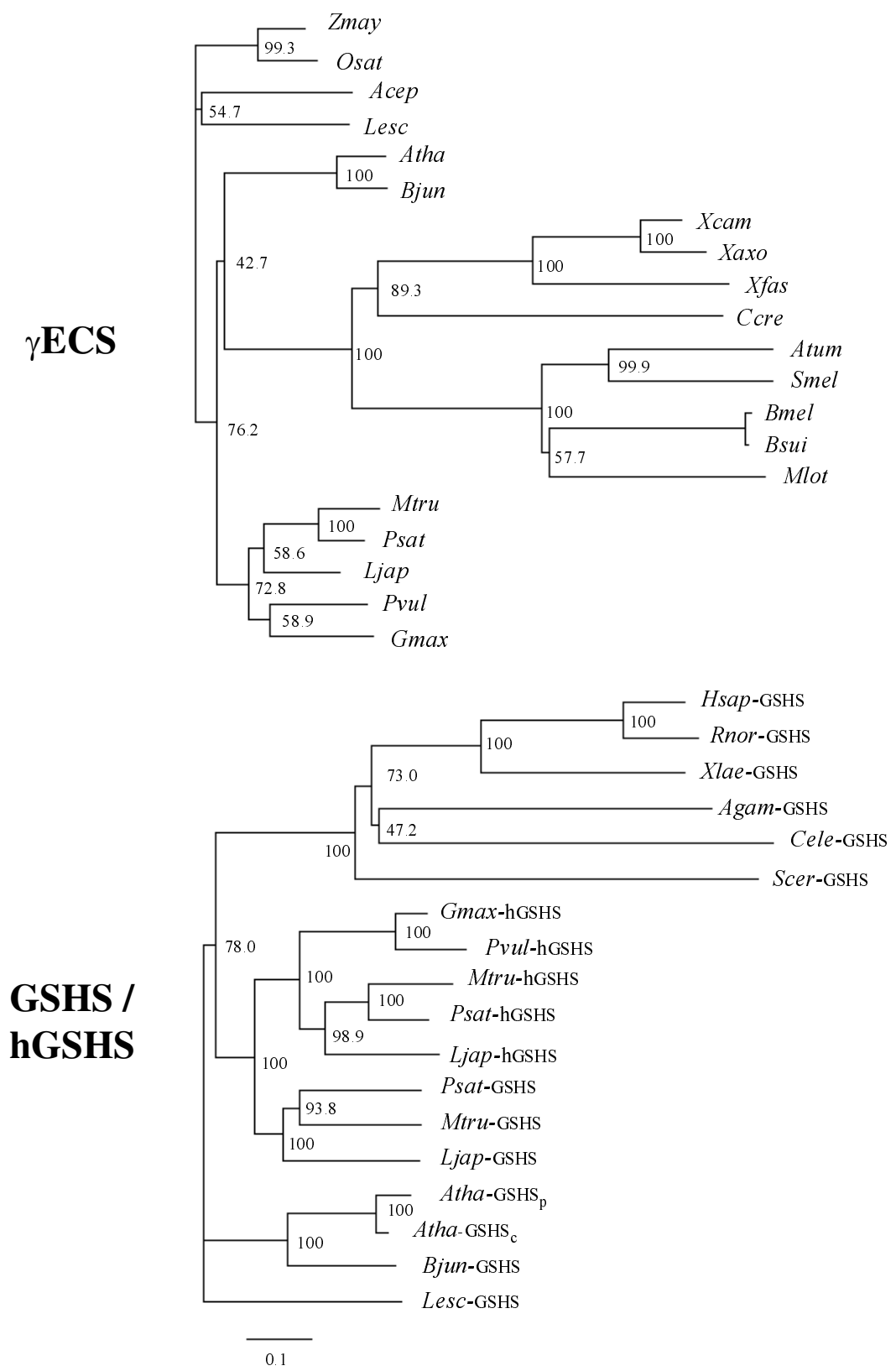

Fig. 1. Phylogenetic analyses of $\gamma$-glutamylcysteine synthetase ( $\gamma$ ECS), glutathione synthetase (GSHS), and homoglutathione synthetase (hGSHS). Unrooted trees were calculated using the neighbor-joining method of CLUSTAL W. Numbers correspond to percentages of 1,000 bootstraps and bar represents 0.1 substitution per site. To construct the tree for $\gamma \mathrm{ECS}$, the following sequences were used: Acep, Allium cepa (AAL61610); Atha, Arabidopsis thaliana (CAA71075); Atum, Agrobacterium tumefaciens (NP_353679); Bjun, Brassica juncea (O23736); Bmel, Brucella melitensis (NP_541506); Bsui, Brucella suis (NP_699940); Ccre, Caulobacter crescentus (NP_422208); Gmax, Glycine max (AAG13459); Lesc, Lycopersicon esculentum (O22493); Ljap, Lotus japonicus (AAO45821); Mlot, Mesorhizobium loti (NP_107315); Mtru, Medicago truncatula (Q9ZNX6); Osat, Oryza sativa (CAD48598); Psat, Pisum sativum (AAF22137); Pvul, Phaseolus vulgaris (AAF22136); Smel, Sinorhizobium meliloti (NP_384876); Zmay, Zea mays (CAC83005). To construct the tree for

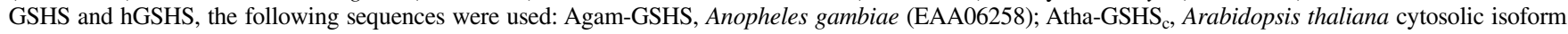
(AAA99146); Atha-GSHS, , Arabidopsis thaliana plastid isoform (CAB51027); Bjun-GSHS, Brassica juncea (CAA71878); Cele-GSHS, Caenorhabditis elegans (NP_063610); Gmax-hGSHS, Glycine max (CAB91078); Hsap-GSHS, Homo sapiens (NP_000169); Lesc-GSHS, Lycopersicon esculentum (AAB71231); Ljap-GSHS, Lotus japonicus (AAK77663); Ljap-hGSHS, Lotus japonicus (AAO92441); Mtru-GSHS, Medicago. truncatula (AAK93946); MtruhGSHS, Medicago truncatula (AAD29849); Psat-GSHS, Pisum sativum (AAF98121); Psat-hGSHS, Pisum sativum (AAF98156); Pvul-hGSHS, Phaseolus vulgaris (AAF98157); Rnor-GSHS, Rattus norvegicus (P46413); Scer-GSHS, Saccharomyces cerevisiae (NP_014593); Xaxo, Xanthomonas axonopodis (NP_641081); Xcam, Xanthomonas campestris (NP_638742); Xfas, Xylella fastidiosa (NP_298717); Xlae-GSHS, Xenopus laevis (P35668). 
more of the three genes contain elements that may be involved in the response of plants to hormones and other growth regulators (auxins; ethylene; gibberellins; and abscisic, salicylic, and methyl jasmonic acids) and to stress conditions (water, heat, cold, and oxidative stress; pathogenesis; anoxia; and wounding). The promoters also contain elements commonly found in light-regulated genes (e.g., GT-1 and GATA motifs) and in many other eukaryotic genes (e.g., TATA and CAAT boxes).

\section{Gene expression.}

Gene-specific primers (Table 3) based on the cDNA sequences were used to analyze expression of recs, gshs, and $h g s h s$ in nodules, roots, and leaves. Primers for $g s h s$ and $h g s h s$ were designed to amplify cDNA products of different size and, thus, confirm specificity. As expected, the primers amplified a single product and did not recognize the $g s h s$ gene of bacteroids. Preliminary experiments were conducted by reverse transcription-polymerase chain reaction (RT-PCR) with different amplification cycles. No major differences in expression were detected for the recs and hgshs genes (data not shown), whereas the gshs transcript was clearly more abundant in nodules than in roots or leaves (Fig. 4). Interestingly, the gshs transcript, but not the corresponding enzyme activity, was found in the leaves, suggesting posttranscriptional regulation.

To quantify expression of all three thiol synthetases and, in particular, to verify enhanced expression of gshs in nodules, we used real-time quantitative RT-PCR. Appropriate primers were adapted from those used for conventional RT-PCR to retain gene specificity (Table 3 ). The recs transcript in leaves was approximately fourfold more abundant than in roots and ninefold more abundant than in nodules (Table 4). The hgshs transcript was most abundant in roots and similarly abundant in the other two plant organs. In contrast, the gshs transcript level in nodules was 22-fold greater than in roots and 15-fold greater than in leaves (Table 4). The higher expression of hgshs in roots was not mirrored by similar increases in hGSHS activity or hGSH content, which again suggests posttranscriptional regulation or in vivo limitation of the enzyme activity.

\section{DISCUSSION}

Legumes are unique among higher plants in that they are able to synthesize both GSH and hGSH. We show here that $L$. japonicus is essentially an hGSH-producing legume because this thiol accounts for $96 \%$ of the total tripeptides in roots and leaves. Interestingly, nodules contain nearly twofold more GSH than hGSH due to a high expression level of GSHS in the nodule plant fraction (this work) as well as in the bacteroids (Moran et al. 2000). The thiol composition of L. japonicus clearly contrasts with that of Medicago truncatula, a model legume that produces exclusively GSH in leaves and the two thiols in roots and nodules (Frendo et al. 1999). These differ- ences should be considered in selecting the model legume for subsequent alteration of thiol metabolism.

The thiol biosynthetic pathway in L. japonicus was further studied by characterizing the relevant genes. The recs gene contains 15 exons interrupted by 14 introns. Except for exon 1 (probably due to differences in signal peptides), all exons are identical or very similar in size to those of Arabidopsis (Cobbett et al. 1998) and rice (accession no. AJ508915), the only two other recs gene structures reported so far in plants. Likewise, the exons of the gshs and hgshs of L. japonicus are almost identical in size and show high sequence homology with those of the gshs of Arabidopsis (Skipsey et al. 1999; Wang and Oliver 1996) and M. truncatula (Frendo et al. 2001). This strongly suggests that the gshs and hgshs genes are highly conserved and originated in legumes by duplication, as proposed by Frendo and associates (2001). This hypothesis is substantiated further by our finding that the two genes of L. japonicus are tandemly arranged and separated by only $8 \mathrm{~kb}$, and also by the unusual AT/AC splicing for intron 6 in both genes. This so-

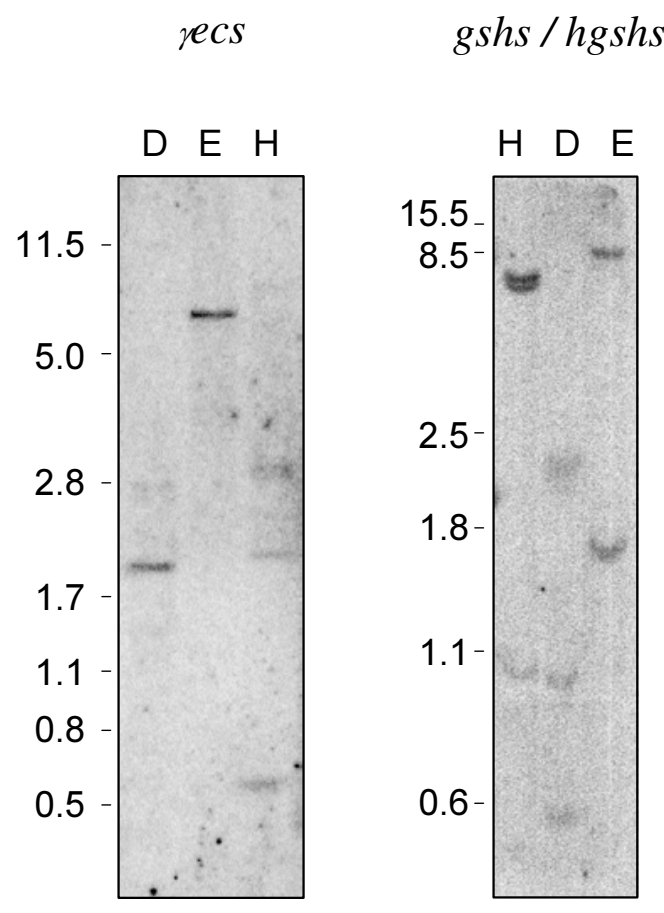

Fig. 3. Genomic Southern analysis of $\gamma$-glutamylcysteine synthetase (recs) and (homo)glutathione synthetase ([h]gshs) genes in Lotus japonicus. DNA (10 $\mu \mathrm{g}$ per lane) was digested with $\operatorname{DraI}$ (D), EcoRI (E), and HindIII (H). Blots were hybridized either with a yecs-specific probe or with a probe that recognizes both gshs and hgshs. Size markers in kilobases are shown on the left.
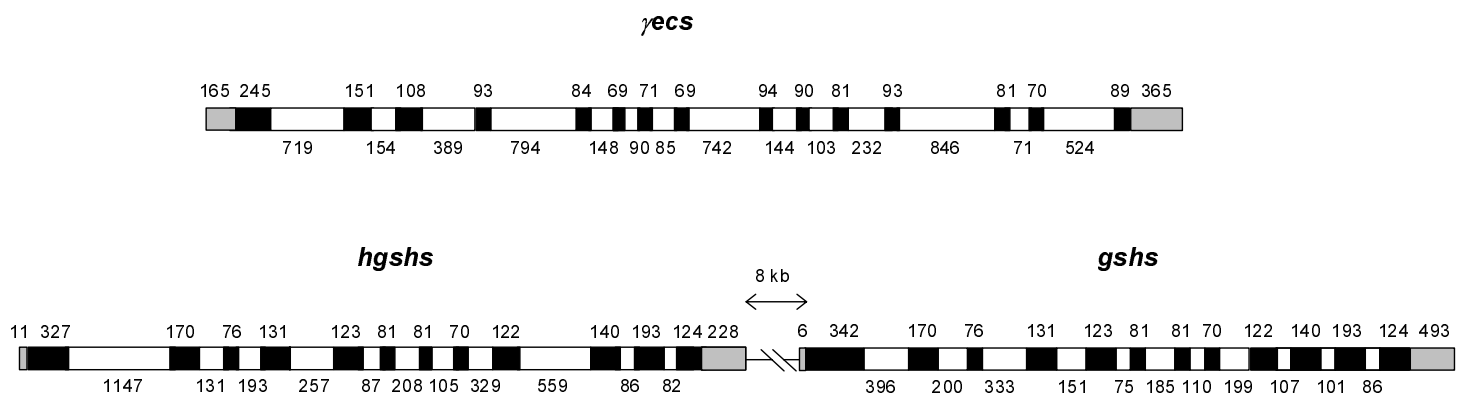

Fig. 2. Structure of the $\gamma$-glutamylcysteine synthetase ( $y e c s)$, glutathione synthetase (gshs), and homoglutathione synthetase (hgshs) genes. The lengths of exons (open reading frames in black boxes; untranslated regions in gray boxes) and introns (white boxes) are given in base pairs. 
called U12-type of intron has an ATATCCTTT consensus sequence at the $5^{\prime}$ splice site and is extremely rare in eukaryotes. In fact, only 11 out of 19,553 introns surveyed in Arabidopsis belong to the U12-type family (Burge et al. 1998). To our knowledge, this noncanonical splice has not been detected yet in any legume, and certainly not during the Lotus sequencing project. Although the regulatory role, if any, of this unusual splice site is unknown, it does mean that a U12-spliceosome has been conserved during plant evolution. There is no apparent relationship in the function of the Arabidopsis genes bearing the unusual introns.

It is noteworthy that two transcript populations were detected for the gshs gene in nodules. Given the similarity and common origin indicated above, it is likely that the same occurs for the hgshs gene in nodules or other plant organs. How- ever, both genes appear to be present as single copies, strongly suggesting alternative splicing of the pre-mRNA to ultimately produce the cytosolic and plastid isoforms. Both subcellular compartments have been reported to contain GSHS activity in other plants (Klapheck et al. 1988; Rennenberg 1997).

The promoter regions of the recs, gshs, and hgshs genes contain cis-acting regulatory elements that may be involved in the plant's response to light, hormones, and stress conditions. Although results of promoter domain analysis obviously require verification with transgenic plants, they are indicative of an intertwined regulation of thiol synthetase genes and underline the central role of GSH in the adaptive response of plants to environmental stress (May et al. 1998). Elements homologous to ARE or NF- $\kappa \mathrm{B}$, associated with the response of animal cells to oxidative stress, also were found in the three promoters, albeit

Table 3. Oligonucleotides used in this study

\begin{tabular}{|c|c|c|c|}
\hline Target gene $^{\mathrm{a}}$ & Sequence $^{b}$ & Use & Amplicon $^{\mathrm{c}}$ \\
\hline \multirow[t]{3}{*}{ yecs } & TAAACTCCCACGTAGAC & cDNA sequencing by primer walking ${ }^{\mathrm{d}}$ & \\
\hline & AGAAGTCCCTGAATGTC & & \\
\hline & TCAGCACAAGTCTGATG & & \\
\hline \multirow[t]{2}{*}{ recs } & AАCTTCTATTTCCTCAAGTATCAGC & Screening of LjT04E19 & 269 \\
\hline & TGCTTATTAATCACGTCTACGTGGG & & \\
\hline \multirow[t]{2}{*}{ recs } & TCATCTCTAАТTATAАACСАCТСC & Mapping of LjT04E19 & 119 \\
\hline & GACTGAGTCAATCAAAATGTG & & \\
\hline \multirow[t]{2}{*}{ recs } & ATGCTGCCCTTTGTTTTTG & RT-PCR ${ }^{\mathrm{e}}$ and Southern analysis & 534 \\
\hline & AACACCTCCGCTACCTCAT & & \\
\hline \multirow[t]{2}{*}{ recs } & GGCATGCTGCCCTTTGTTT & Real-time RT-PCR & 107 \\
\hline & TCGATATATTTGTGTTTCCGATAGACA & & \\
\hline \multirow[t]{2}{*}{ gshs } & CG[A/C]AACATGTA[C/T]GA[C/T]CA [A/G]CATT & Isolation of GSHS cDNA clone (internal fragment) & 464 \\
\hline & ССТTCТСТ[C/T]TG[A/G]GG[C/T]TTCAT & & \\
\hline \multirow[t]{2}{*}{ gshs } & GCAATTAACCCTCACTAAAGGG (T3) & Isolation of GSHS cDNA clone ( $5^{\prime}$ end $)$ & 1,012 \\
\hline & GTAGTCTGGCTCTCCATTCTG & & \\
\hline \multirow[t]{2}{*}{ gshs } & GGCAGAAGTTGATCGAGAAGG & Isolation of GSHS cDNA clone ( $3^{\prime}$ end) & 1,193 \\
\hline & GCGTAATACGACTCACTATAGGGC (T7) & & \\
\hline \multirow[t]{2}{*}{ gshs } & TCGACTCACACTTTCTCTACCG & Screening of LjT44N05 & 144 \\
\hline & TGGAACCGTTACCATTGACA & & \\
\hline \multirow[t]{2}{*}{ gshs } & TGGCTCAACAACAACAACAT & RT-PCR & 535 \\
\hline & GTGACAAGACTCCCTAAACCA & & \\
\hline \multirow[t]{2}{*}{ gshs } & AACACTATTTCCTCTTCATTTGCTGG & Real-time RT-PCR & 53 \\
\hline & TGAAGTTCAGTGACAAGACTCCCTAA & & \\
\hline \multirow[t]{2}{*}{ hgshs } & AGGTGGATGTGGATCTGGTT & Screening of LjT44N05 & 219 \\
\hline & TCGAAGCTGGAAGAATCGTT & & \\
\hline \multirow[t]{2}{*}{ hgshs } & ATGGGGGTAGGTGGATGT & RT-PCR & 408 \\
\hline & CAGTAACTTTCAGGTAATGG & & \\
\hline \multirow[t]{2}{*}{ hgshs } & AAAAGTTCCTGGTGTGGGCTT & Real-time RT-PCR & 77 \\
\hline & GCTTCCAGTAACTTTCAGGTAATGG & & \\
\hline \multirow[t]{2}{*}{ gshs, hgshs } & AAGTACTTAAGTTTGTGTTAATGAC & Mapping of LjT44N05 & 161 \\
\hline & AAATGATTATTAATATTGACCTTTG & & \\
\hline \multirow[t]{2}{*}{ gshs, hgshs } & CTGATGGAGCAATCCTCTGC & Generation of probe for Southern analysis & 382 \\
\hline & AACCATTGCGCATCAAAACT & & \\
\hline \multirow[t]{2}{*}{$\beta$-actin } & GCATTGTTGGTCGTCCTCGT & Real-time RT-PCR & 79 \\
\hline & TGTGCCTCATCCCCAACATA & & \\
\hline
\end{tabular}

${ }^{\mathrm{a}} \gamma$ ecs $=\gamma$-glutamylcysteine synthetase, gshs $=$ glutathione synthetase, and hgshs $=$ homoglutathione synthetase .

${ }^{\mathrm{b}}$ Sequences $\left(5^{\prime} \rightarrow 3^{\prime}\right)$ of the forward (upper line) and reverse (lower line) primers.

${ }^{\mathrm{c}}$ Size of amplified fragment in base pairs.

${ }^{\mathrm{d}}$ Three forward primers were used for sequencing by the primer walking method.

${ }^{\mathrm{e}} \mathrm{RT}-\mathrm{PCR}=$ reverse-transcription polymerase chain reaction.

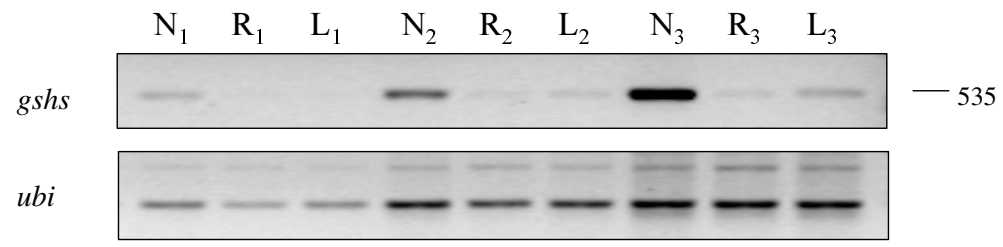

Fig. 4. Enhanced expression of glutathione synthetase ( $g$ shs) in nodules of Lotus japonicus. Reverse transcription-polymerase chain reaction of RNA isolated from nodules (N), roots (R), and leaves (L) was performed as described in Materials and Methods. For gshs (amplicon of 535 bp), the reactions were stopped after 32 (1), 34 (2), or 36 (3) amplification cycles. For ubiquitin (ubi), which was used to ensure uniform loading, the reactions were stopped after 24 (1), 26 (2), or 28 (3) amplification cycles. 
with a minimal mismatch (1 to $2 \mathrm{bp}$ ). Such elements also were observed in two other antioxidant genes of plants, catalase (Scandalios et al. 1997) and superoxide dismutase (Kernodle and Scandalios 2001).

Differential regulation of the three genes was evident in considering the distribution of transcripts, enzyme activities, and thiols within the plant. The recs and hgshs transcripts were most abundant in the leaves and roots, respectively, whereas both plant organs showed a very low expression of gshs. In contrast, nodules have high levels of $g s h s$ transcript, GSHS activity, and GSH, indicating that the gene is fully functional and may play a critical role in the symbiosis. We can only surmise at this stage that the role of GSH is related to nodule formation, protection of $\mathrm{N}_{2}$ fixation in the infected zone, or both. Thus, our previous studies with pea and common bean nodules, which are amenable for careful tissue dissection, showed that the $\gamma$ ECS activity and GSH content are highest in the apical zone of indeterminate nodules and in the infected zone of determinate nodules, whereas the hGSH content is higher in the cortex (Matamoros et al. 1999). Also, a role of GSH in nodule formation may be envisaged, given that this thiol is involved in cell division in meristems (Sánchez-Fernández et al. 1997; Vernoux et al. 2000), a key process in nodule formation (Mylona et al. 1995).

Phylogenetic analysis of the $\gamma \mathrm{ECS}$ of $L$. japonicus reveals high homology (80 to $90 \%$ identity) with other plants, moderate homology (56 to 60\%) with bacteria of the Rhizobiales and other proteobacteria, and poor homology (18 to 27\%) with $E$. coli, yeast, and animals. These observations suggest at least three clades in the evolution of $\gamma E C S$ and provide only partial support to the proposal of May and Leaver (1994) that there is considerable structural heterogenity among the $\gamma$ ECS from several organisms, and even within the enzymes from higher plants. In fact, the calculated molecular mass of $56 \mathrm{kDa}$ for $L$. japonicus $\gamma$ ECS is very similar to those of Arabidopsis, tobacco, pea, and bean (Hell and Bergmann 1990; Matamoros et al. 1999; May and Leaver 1994). The enzyme from tobacco is, however, dissociated into two equal subunits by thiol reagents (Hell and Bergmann 1990). Therefore, differences in tertiary or quaternary structure may exist between the $\gamma E C S$ of plants. The phylogenetic analysis of the GSHS and hGSHS of L. japonicus shows high homology with other plants (63 to $90 \%$ identity), significant homology (37 to 44\%) with yeast and animals, and virtually no homology $(<25 \%)$ with prokaryotes. The molecular mass of 55.0 to $61.3 \mathrm{kDa}$ expected for L. japonicus GSHS and hGSHS also is similar to that of other plants (Rawlins et al. 1995; Rennenberg 1997) and suggests that the native enzyme is a homodimer, as occurs for other eukaryotes (Rennenberg 1997). Given the importance of thiol metabolism for most life forms, it will be of interest to determine whether the differences (or similarities) in the structures of $\gamma$ ECS and GSHS among the various groups of organisms reflect distinct (or similar) catalytic and regulatory properties of the enzymes.

\section{MATERIALS AND METHODS}

\section{Plant material.}

Seeds of L. japonicus ('Gifu' B-129) were gently scarified and germinated for 2 days in petri dishes. Seedlings were then transferred to pots containing vermiculite, inoculated 2 days later with Mesorhizobium loti strain NZP2235, and grown under controlled environment conditions for 44 to 50 days (Handberg and Stougaard 1992). Plants were fed with B\&D nutrient solution (Broughton and Dilworth 1971) supplemented with $0.25 \mathrm{mM} \mathrm{NH} \mathrm{NO}_{3}$. Nodules, roots, and leaves were harvested in liquid nitrogen and stored at $-80^{\circ} \mathrm{C}$ for subsequent analysis.

\section{Thiol tripeptide contents and thiol tripeptide synthetase activities.}

All extraction procedures were performed at $4^{\circ} \mathrm{C}$. Thiol compounds were extracted from $50 \mathrm{mg}$ of plant tissue with $500 \mu \mathrm{l}$ of $200 \mathrm{mM}$ methanesulfonic acid containing $0.5 \mathrm{mM}$ diethylenetriaminepentaacetic acid. Extracts were cleared by centrifugation at $14,000 \times g$ for $5 \mathrm{~min}$, and thiols were derivatized with monobromobimane and quantified by high-performance liquid chromatography (HPLC) with fluorescence detection (Matamoros et al. 1999). Thiol synthetases were extracted from $50 \mathrm{mg}$ of plant tissue with $500 \mu \mathrm{l}$ of an optimized medium consisting of 50 $\mathrm{mM}$ Tris- $\mathrm{HCl}$ (pH 8.0), $0.2 \mathrm{mM}$ EDTA, $10 \mathrm{mM} \mathrm{MgCl}_{2}$, and $10 \%$ glycerol. Extracts were centrifuged at $14,000 \times g$ for 10 min and depleted of low molecular mass compounds with Centricon-10 devices (Amicon, Danvers, MA, U.S.A.). The activities were then assayed based on the HPLC quantification of the synthesized GSH and hGSH (Matamoros et al. 1999).

\section{Isolation and characterization of cDNA clones.}

A single EST (MR068f07) encoding $\gamma$ ECS was obtained from a root cDNA library. No corresponding ESTs were found in either leaf or nodule cDNA libraries. A primer (Table 3) was designed based on the $3^{\prime}$ end EST sequence (accession no. $\mathrm{AB} 084239$ ), and the complete sequence of the cDNA clone was determined using the primer walking method (Voss et al. 1993). Two additional primers were obtained from the walking

Table 4. Real-time reverse-transcription polymerase chain reaction analysis of thiol synthetase gene expression in roots (R), nodules (N), and leaves (L) of Lotus japonicus

\begin{tabular}{|c|c|c|c|c|c|}
\hline Gene $^{a}$ & Organ & $\mathrm{C}_{\mathrm{t}}^{\mathrm{b}}$ & $\Delta \mathbf{C}_{t}^{\mathbf{c}}$ & $\Delta \Delta \mathbf{C}_{\mathbf{t}}^{\mathbf{d}}$ & $\mathbf{R}^{\mathbf{e}}$ \\
\hline \multirow[t]{3}{*}{ yecs } & $\mathrm{R}$ & 32.51 & 3.39 & 0 & 1 \\
\hline & $\mathrm{N}$ & 32.96 & 4.45 & 1.06 & 0.4 \\
\hline & $\mathrm{L}$ & 27.62 & 3.73 & 0.35 & 3.7 \\
\hline \multirow[t]{3}{*}{ gshs } & $\mathrm{R}$ & 34.56 & 5.44 & 0 & 1 \\
\hline & $\mathrm{N}$ & 29.50 & 0.99 & -4.45 & 21.8 \\
\hline & $\mathrm{L}$ & 32.88 & 4.88 & -0.56 & 1.5 \\
\hline \multirow[t]{3}{*}{ hgshs } & $\mathrm{R}$ & 31.04 & 1.91 & 0 & 1 \\
\hline & $\mathrm{N}$ & 31.22 & 2.71 & 0.80 & 0.6 \\
\hline & $\mathrm{L}$ & 31.29 & 3.29 & 1.38 & 0.4 \\
\hline \multirow[t]{3}{*}{$\beta$-actin } & $\mathrm{R}$ & 29.13 & $\ldots$ & $\ldots$ & $\ldots$ \\
\hline & $\mathrm{N}$ & 28.51 & $\ldots$ & $\ldots$ & $\ldots$ \\
\hline & $\mathrm{L}$ & 28.00 & $\ldots$ & $\ldots$ & $\ldots$ \\
\hline
\end{tabular}

a yecs $=\gamma$-glutamylcysteine synthetase, gshs $=$ glutathione synthetase, and hgshs $=$ homoglutathione synthetase.

b Average threshold cycle number.

${ }^{c}$ Difference in cycle number between thiol synthetase genes and control gene.

${ }^{\mathrm{d}}$ Difference in cycle number relative to roots.

e Transcript relative abundance calculated as $2^{-\Delta \Delta C t}$. 
(Table 3) and the sequences generated in the three rounds of walks were assembled to obtain the complete cDNA sequence.

The cDNA clones encoding GSHS were isolated by PCR screening of a L. japonicus nodule cDNA library using degenerate primers (Table 3) based on plant GSHS cDNAs (Moran et al. 2000). The PCR mix contained $0.2 \mu \mathrm{M}$ of both primers, $0.2 \mathrm{mM}$ dNTPs, $1.5 \mathrm{mM} \mathrm{MgCl} 2,0.05 \% \mathrm{~W}-1$ detergent, and 1.5 $\mathrm{U}$ of Taq polymerase (Life Technologies, Paisley, U.K.) in a final volume of $25 \mu \mathrm{l}$. The "touchdown" PCR cycling protocol consisted of $3 \mathrm{~min}$ at $95^{\circ} \mathrm{C}, 6$ cycles $\left(75 \mathrm{~s}\right.$ at $95^{\circ} \mathrm{C}, 60 \mathrm{~s}$ at $59^{\circ} \mathrm{C}$ decreasing by $0.5^{\circ} \mathrm{C}$ every cycle, $90 \mathrm{~s}$ at $\left.72^{\circ} \mathrm{C}\right), 35$ cycles $(75 \mathrm{~s}$ at $95^{\circ} \mathrm{C}, 60 \mathrm{~s}$ at $56^{\circ} \mathrm{C}, 90 \mathrm{~s}$ at $72^{\circ} \mathrm{C}$ ), and $10 \mathrm{~min}$ at $72^{\circ} \mathrm{C}$. A fragment of approximately $460 \mathrm{bp}$ was obtained, cloned in pCRII (Invitrogen, Carlsbad, CA, U.S.A.), and sequenced. To amplify the $5^{\prime}$ and $3^{\prime}$ ends, a new set of specific $L$. japonicus GSHS primers (Table 3) were designed based on the internal sequence and used in combination with $\mathrm{T} 7$ and $\mathrm{T} 3$ primers. The PCR mix was separated in $1 \%$ agarose gels and the top bands were cloned in pCRII and sequenced.

The same set of specific GSHS primers (Table 3) were used, in combination with T3 and T7 primers, to isolate the hGSHS cDNA clones by PCR screening of a L. japonicus leaf cDNA library.

\section{Isolation, characterization, and mapping of genes.}

A genomic library of L. japonicus accession 'Miyakojima' MG-20 was generated with the TAC vector (Liu et al. 1999). Oligonucleotides (Table 3) were synthesized based on cDNA sequences and used as primers for PCR screening of the TAC library according to the three-dimensional pooling method (Sato et al. 2001). PCR products were sequenced to confirm authenticity of screening. The nucleotide sequence of each TAC insert was determined according to the bridging shotgun method and genes were mapped using simple sequence repeat markers found in the TAC sequences (Sato et al. 2001). Appropriate primers (Table 3) were used for mapping of yecs in the TAC clone LjT04E19 and of $g s h s$ and hgshs in the TAC clone LjT44N05.

\section{Analysis of cDNA, gene, and deduced protein sequences.}

Sequence alignments and phylogenetic trees were done with CLUSTAL W 1.7 (Thompson et al. 1994). Identity and homology calculations were performed with Gap (Genetics Computer Group, Madison, WI, U.S.A.) and BLAST (Altschul et al. 1997). Regulatory elements in the promoter regions were searched with PLACE (Higo et al. 1999) and PlantCARE (Lescot et al. 2002). Predictions of subcellular localization and analysis of signal peptides were performed with MitoProtII (Claros 1995), PSORT (Nakai and Kanehisa 1992), and ChloroP and TransitP (Center for Biological Sequence Analysis, Technical University of Denmark, Lyngby).

\section{Southern analysis.}

Genomic DNA was isolated from leaves and flowers according essentially to the cetyltrimethylammonium bromide method (Aldrich and Cullis 1993). DNA digested with restriction enzymes was fractionated on $0.7 \%$ agarose gels and transferred to nylon membranes (Hybond- $\mathrm{N}^{+}$; Amersham Biosciences, Uppsala, Sweden). Probes for recs and gshs/hgshs were PCR generated using the primers indicated in Table 3 and labeled with ${ }^{32} \mathrm{P}-\mathrm{dCTP}$ by random priming (Megaprime; Amersham Biosciences). Hybridizations were carried out at $65^{\circ} \mathrm{C}$ overnight with a standard buffer consisting of $5 \times \mathrm{SSC}(1 \times \mathrm{SSC}$ is $0.15 \mathrm{M} \mathrm{NaCl}$ plus $0.015 \mathrm{M}$ sodium citrate), $5 \times$ Denhardt solution ( $1 \times$ Denhardt is $0.02 \%$ Ficoll $400,0.02 \%$ polyvinylpyrrolidone, and $0.02 \%$ bovine serum albumin), $0.5 \%$ sodium dodecyl sulfate (SDS), and salmon sperm DNA at $20 \mu \mathrm{g} / \mathrm{ml}$
(Sambrook et al. 1989). The membrane then was rinsed at $65^{\circ} \mathrm{C}$ successively with $2 \times \mathrm{SSC}, 1 \times \mathrm{SSC}$, and $0.5 \times \mathrm{SSC}$ for 15 min each. All SSC solutions contained $0.1 \%$ SDS. Hybridization signals were scanned and imaged with a Molecular Imager FX (Bio-Rad, Hercules, CA, U.S.A.).

\section{Gene expression analysis.}

Total RNA was isolated from nodules, roots, and leaves using the RNAqueous kit from Ambion (Austin, TX, U.S.A.). For RTPCR, total RNA ( $5 \mu \mathrm{g}$ ) was treated with DNase I (Roche, Mannheim, Germany) and reverse transcribed with Moloney murine leukemia virus reverse transcriptase (Promega Corp., Madison, WI, U.S.A.) in the presence of RNase inhibitor (Roche). The RNA was shown to be free of genomic DNA by performing control reactions, with ubiquitin primers, in which the reverse transcription step was omitted. No PCR product was detected after 37 cycles. The amplicons of recs, gshs, and hgshs were shown to correspond to cDNA and not to genomic DNA because, for each gene, the forward and reverse primers were designed to sequences on different exons. The absence of contaminating genomic DNA also was confirmed by real-time RT-PCR analysis: heat dissociation curves showed a single PCR product for each gene and parallel analysis with genomic DNA showed that this amplified 6 to 7 cycles earlier than the cDNA.

For RT-PCR at different amplification cycles, the PCR mix contained $0.5 \mathrm{mM}$ dNTPs, $0.2 \mu \mathrm{M}$ primers (Table 3), and $1 \mathrm{U}$ of DNA polymerase from Thermus thermophilus (Biotools, Madrid, Spain) in a final volume of $25 \mu$. PCR conditions were $5 \mathrm{~min}$ at $94^{\circ} \mathrm{C}$, the number of cycles $\left(30 \mathrm{~s}\right.$ at $94^{\circ} \mathrm{C}, 40 \mathrm{~s}$ at $54^{\circ} \mathrm{C}, 30 \mathrm{~s}$ at $72^{\circ} \mathrm{C}$ ) stated in the legend to Figure 4, and 10 min at $72^{\circ} \mathrm{C}$. Ethidium bromide-stained gels were visualized with a Gel Doc 2000 (Bio-Rad).

For real-time RT-PCR, primers were designed using Primer Express software (Applied Biosystems, Foster City, CA, U.S.A.). The PCR mix contained $0.3 \mu \mathrm{M}$ each primer and $10 \mu \mathrm{l}$ of SYBR Green I PCR Master Mix in a total volume of $20 \mu \mathrm{l}$. Reactions were amplified in an ABI Prism 7000 Sequence Detection System following a standard cycling protocol: 10 min at $95^{\circ} \mathrm{C}$ and 40 cycles $\left(15 \mathrm{~s}\right.$ at $95^{\circ} \mathrm{C}, 1 \mathrm{~min}$ at $\left.60^{\circ} \mathrm{C}\right)$. Heat dissociation curves showed that a single PCR product was amplified for each gene and that there was no cross-hybridization between $g s h s$ and $h g s h s$. Melting temperatures were $76.1^{\circ} \mathrm{C}$ for the PCR products of recs and hgshs and $71.2^{\circ} \mathrm{C}$ for the PCR product of gshs.

\section{ACKNOWLEDGMENTS}

This research was supported by grants DP0210101 (to J. Stiller) from the Australian Research Council (Australia) and PB98-0522 (to M. Becana) from the Dirección General de Investigación Científica (Spain). M. A. Matamoros was the recipient of a postdoctoral fellowship from the Gobierno Vasco (Spain). We thank M. Viribay (Applied Biosystems) for real-time RT-PCR analysis, J. Stougaard for providing cDNA libraries, J. Webb for providing seeds, C. Pérez-Rontomé for help with HPLC and figures, and I. Iturbe-Ormaetxe for advice on Northern blots.

\section{LITERATURE CITED}

Aldrich, J., and Cullis, C. A. 1993. RAPD analysis in flax: optimization of yield and reproducibility using Klen 1 DNA polymerase, Chelex 100 and gel purification of genomic DNA. Plant Mol. Biol. Rep. 11:128-141.

Altschul, S. F., Madden, T. L., Schaffer, A. A., Zhang, J., Zhang, Z., Miller, W., and Lipman, D. J. 1997. Gapped BLAST and PSI-BLAST: a new generation of protein database search programs. Nucleic Acid Res. 25:3389-3402.

Broughton, B. J., and Dilworth, M. J. 1971. Control of leghaemoglobin synthesis in snake beans. Biochem. J. 125:1075-1080.

Burge, C. B., Padgett, R. A., and Sharp, P. A. 1998. Evolutionary fates and origins of U12-type introns. Mol. Cell 2:773-785. 
Claros, M. G. 1995. MitoProt, a Macintosh application for studying mitochondrial proteins. Comp. Appl. Biosci. 11:441-447.

Cobbett, C. S., May, M. J., Howden, R., and Rolls, B. 1998. The glutathione-deficient, cadmium-sensitive mutant, cad2-1, of Arabidopsis thaliana is deficient in $\gamma$-glutamylcysteine synthetase. Plant $\mathbf{J}$. 16:73-78.

Frendo, P., Gallesi, D., Turnbull, R., Van de Sype, G., Hérouart, D., and Puppo, A. 1999. Localisation of glutathione and homoglutathione in Medicago truncatula is correlated to a differential expression of genes involved in their synthesis. Plant J. 17:215-219.

Frendo, P., Hernández, M. J., Mathieu, C., Duret, L., Gallesi, D., Van de Sype, G., Hérouart, D., and Puppo, A. 2001. A Medicago truncatula homoglutathione synthetase is derived from glutathione synthetase by gene duplication. Plant Physiol. 126:1706-1715.

Handberg, K., and Stougaard, J. 1992. Lotus japonicus, an autogamous, diploid legume species for classical and molecular genetics. Plant J. 2:487-496.

Hell, R., and Bergmann, L. 1990. $\gamma$-Glutamylcysteine synthetase in higher plants: catalytic properties and subcellular localization. Planta 180:603-612.

Higo, K., Ugawa, Y., Iwamoto, M., and Korenaga, T. 1999. Plant cis-acting regulatory DNA elements (PLACE) database. Nucleic Acids Res. 27:297-300.

Kaneko, T., Nakamura, Y., Sato, S., Asamizu, E., Kato, T., Sasamoto, S., Watanabe, A., Idesawa, K., Ishikawa, A., Kawashima, K., Kimura, T., Kishida, Y., Kiyokawa, C., Kohara, M., Matsumoto, M., Matsuno, A., Mochizuki, Y., Nakayama, S., Nakazaki, N., Shimpo, S., Sugimoto, M., Takeuchi, C., Yamata, M., and Tabata, S. 2000. Complete gene structure of the nitrogen-fixing symbiotic bacterium Mesorhizobium loti. DNA Res. 7:331-338.

Kato, T., Kaneko, T., Sato, S., Nakamura, Y., and Tabata, S. 2000. Complete structure of the chloroplast genome of a legume, Lotus japonicus. DNA Res. 7:323-330.

Kernodle, S. P., and Scandalios, J. G. 2001. Structural organization, regulation, and expression of the chloroplastic superoxide dismutase Sod1 gene in maize. Arch. Biochem. Biophys. 391:137-147.

Klapheck, S. 1988. Homoglutathione: isolation, quantification and occurrence in legumes. Physiol. Plant. 74:727-732.

Klapheck, S., Zopes, H., Levels, H.-G., and Bergmann, L. 1988. Properties and localization of the homoglutathione synthetase from Phaseolus coccineus leaves. Physiol. Plant. 74:733-739.

Lescot, M., Déhais, P., Moreau, Y., De Moor, B., Rouzé, P., and Rombauts, S. 2002. PlantCARE: a database of plant cis-acting regulatory elements and a portal to tools for in silico analysis of promoter sequences. Nucleic Acids Res. 30:325-327.

Liu, Y.-G., Shirano, Y., Fukaki, H., Yanai, Y., Tasaka, M., Tabata, S., and Shibata, D. 1999. Complementation of plant mutants with large genomic DNA fragments by a transformation-competent artificial chromosome vector accelerates positional cloning. Proc. Natl. Acad. Sci. U.S.A. 96:6535-6549.

Macnicol, P. K., and Bergmann, L. 1984. A role for homoglutathione in organic sulfur transport to the developing mung bean seed. Plant Sci. Lett. 36:219-223.

Matamoros, M. A., Moran, J. F., Iturbe-Ormaetxe, I., Rubio, M. C., and Becana, M. 1999. Glutathione and homoglutathione synthesis in legume root nodules. Plant Physiol. 121:879-888.

May, M. J., and Leaver, C. J. 1994. Arabidopsis thaliana $\gamma$-glutamylcysteine synthetase is structurally unrelated to mammalian, yeast, and Escherichia coli homologs. Proc. Natl. Acad. Sci. U.S.A. 91:10059-10063.

May, M. J., Vernoux, T., Leaver, C., Van Montagu, M., and Inzé, D. 1998. Glutathione homeostasis in plants: implications for environmental sensing and plant development. J. Exp. Bot. 49:649-667.

Moran, J. F., Iturbe-Ormaetxe, I., Matamoros, M. A., Rubio, M. C., Clemente, M. R., Brewin, N. J., and Becana, M. 2000. Glutathione and homoglutathione synthetases of legume nodules. Cloning, expression, and subcellular localization. Plant Physiol. 124:1381-1392.
Mylona, P., Pawlowski, K., and Bisseling, T. 1995. Symbiotic nitrogen fixation. Plant Cell 7:869-885.

Nakai, K., and Kanehisa, M. 1992. A knowledge base for predicting protein localization sites in eukaryotic cells. Genomics 14:897-911.

Nakamura, Y., Kaneko, T., Asamizu, E., Kato, T., Sato, S., and Tabata, S. 2002. Structural analysis of a Lotus japonicus genome. II. Sequence features and mapping of sixty-five TAC clones which cover the 6.5$\mathrm{Mb}$ regions of the genome. DNA Res. 9:63-70.

Rawlins, M. R., Leaver, C. J., and May, M. J. 1995. Characterisation of an Arabidopsis thaliana cDNA encoding glutathione synthetase. FEBS (Fed. Eur. Biochem. Soc.) Lett. 376:81-86.

Rennenberg, H. 1997. Molecular approaches to glutathione biosynthesis. Pages 59-70 in: Sulphur Metabolism in Higher Plants. W. J. Cram, L. J. DeKok, I. Stulem, C. Brunold, and H. Rennenberg, eds. Backhuys Publishers, Leiden, The Netherlands.

Sambrook, J., Fritsch, E. F., and Maniatis, T. 1989. Molecular Cloning: A Laboratory Manual. 2nd ed. Cold Spring Harbor Laboratory Press, Cold Spring Harbor, NY.

Sánchez-Fernández, R., Fricker, M., Corben, L. B., White, N. S., Sheard, N., Leaver, C. J., Van Montagu, M., Inzé, D., and May, M. J. 1997. Cell proliferation and hair tip growth in the Arabidopsis root are under mechanistically different forms of redox control. Proc. Natl. Acad. Sci. U.S.A. 94:2745-2750

Sato, S., Kaneko, T., Nakamura, Y., Asamizu, E., Kato, T., and Tabata, S. 2001. Structural analysis of a Lotus japonicus genome. I. Sequence features and mapping of fifty-six TAC clones which cover the 5.4-Mb regions of the genome. DNA Res. 8:311-318.

Scandalios, J. G., Guan, L., and Polidoros, A. N. 1997. Catalases in plants: gene structure, properties, regulation, and expression. Pages 343-406 in: Oxidative Stress and the Molecular Biology of Antioxidant Defenses. J. G. Scandalios, ed. Cold Spring Harbor Laboratory Press, Cold Spring Harbor, NY.

Shapiro, M. B., and Senapathy, P. 1987. RNA splice junctions of different classes of eukaryotes: sequence statistics and functional implications in gene expression. Nucleic Acids Res. 15:7155-7174.

Skipsey, M., Andrews, C. J., Townson, J. K., Jepson, I., and Edwards, R. 1999. Isolation of cDNA (AJ243813) and genomic clones (AJ243812) of glutathione synthetase containing plastidic targeting sequences from Arabidopsis thaliana. Plant Physiol. 121:312.

Thompson, J. D., Higgins, D. G., and Gibson, T. J. 1994. CLUSTAL W: improving the sensitivity of progressive multiple sequence alignment through sequence weighting, positions-specific gap penalties and weight matrix choice. Nucleic Acids Res. 22:4673-4680.

Ullmann, P., Gondet, L., Potier, S., and Bach, T. J. 1996. Cloning of Arabidopsis thaliana glutathione synthetase $(\mathrm{GSH} 2)$ by functional complementation of a yeast $g s h 2$ mutant. Eur. J. Biochem. 236:662-669.

Vernoux, T., Wilson, R. C., Seeley, K. A., Reichheld, J.-P., Muroy, S., Brown, S., Maughan, S. C., Cobbett, C. S., Van Montagu, M., Inzé, D. May, M. J., and Sung, Z. R. 2000. The ROOT MERISTEMLESS1/CADMIUM SENSITIVE2 gene defines a glutathione-dependent pathway involved in initiation and maintenance of cell division during postembryonic root development. Plant Cell 12:97-109.

Voss, H., Wiemann, S., Grothues, D., Sensen, C., Zimmermann, J., Schwager, C., Stegemann, J., Erfle, H., Rupp, T., and Ansorge, W. 1993. Automated low-redundancy large-scale DNA sequencing by primer walking. Biotechniques 15:714-721

Wang, C. L., and Oliver, D. J. 1996. Cloning of the cDNA and genomic clones for glutathione synthetase from Arabidopsis thaliana and complementation of a gsh2 mutant in fission yeast. Plant Mol. Biol. 31:1093-1104

Wang, C. L., and Oliver, D. J. 1997. Identification of a putative flexible loop in Arabidopsis glutathione synthetase. Biochem. J. 322:241-244.

Zenk, M. H. 1996. Heavy metal detoxification in higher plants-a review. Gene 179:21-30.

Zopes, H., Klapheck, S., and Bergmann, L. 1993. The function of homoglutathione and hydroxymethylglutathione for the scavenging of hydrogen peroxide. Plant Cell Physiol. 34:515-521. 